\title{
PENGARUH KUNJUNGAN WISATAWAN TERHADAP PENDAPATAN ASLI DAERAH KOTA BANDA ACEH TAHUN 2012 - 2015
}

\author{
Yushita Marini \\ Ekonomi Akuntansi, Universitas Terbuka, Jl. Pendidikan/Bahagia, email: \\ yushita@ecampus.ut.ac.id
}

\begin{abstract}
Banda Aceh is one of the city of Islamic tourism in Indonesia, therefore it is expected that regional income can be obtained from tourism income. As a source of revenue of income, tourism is influenced by tourist visits. This study aims to determine whether there is influence between the visiting of the domestic tourists and the foreign tourists to the regional revenue in the city of Banda Aceh. This research uses quantitative approach and data analysis used is simple regression analysis. The source of this research is taken from the Banda Aceh Statistics Data Report 2012 to 2015. The results show that there is influence between the visit of tourists to the city's original revenue of Banda Aceh, this is indicated by the increase of the number of tourists to increase the original income of the regional.
\end{abstract}

\section{Keywords : tourist visit, regional income.}

\begin{abstract}
Abstrak: Banda Aceh merupakan salah satu kota wisata syariah yang ada di Indonesia, karenanya diharapkan pendapatan daerahnya dapat diperoleh dari pendapatan pariwisata. Sebagai sumber penerimaan pendapatan, pariwisata dipengaruhi oleh kunjungan wisatawan. Penelitian ini bertujuan untuk mengetahui apakah terdapat pengaruh antara jumlah kunjungan wisatawan nusantara dan mancanegara terhadap pendapatan daerah di Kota Banda Aceh. Penelitian ini menggunakan pendekatan kuantitatif dan analisis data yang digunakan adalah analisis regresi sederhana. Sumber penelitian ini diambil dari Laporan Data Statistik Banda Aceh tahun 2012 sampai dengan 2015. Hasil penelitian menunjukkan bahwa terdapat pengaruh antara jumlah wisatawan terhadap pendapatan asli daerah kota Banda Aceh, hal ini ditunjukkan dari peningkatan jumlah wisatawan terhadap peningkatan pendapatan asli daerahnya.
\end{abstract}

\section{Kata kunci : kunjungan wisatawan, pendapatan asli daerah}

Indonesia sebagai Negara Republik

Kesatuan yang menganut asas desentralisasi dalam penyelenggaraan pemerintahan dengan memberikan kesempatan dan keleluasaan kepada Daerah untuk menyelenggarakan Otonomi Daerah. Banda Aceh merupakan salah satu daerah yang juga menerapkan Otonomi daerah yang berlandaskan undang-undang Nomor 32 Tahun 2004 tentang Pemerintah Daerah yang merupakan hak, wewenang dan kewajiban daerah otonom untuk mengatur dan mengurus sendiri urusan pemerintahan dan kepentingan masyarakat setempat sesuai dengan peraturan perundang-undangan. Pelaksanaan Otonomi Daerah disusun untuk dapat terwujudnya kesejahteraan masyarakat melalui peningkatan, pelayanan, pemberdayaan, dan peran serta masyarakat. Salah satu sumber keuangan daerah yang dimiliki dan dikelola oleh Pemerintah Daerah adalah Pendapatan Asli Daerah (PAD), merupakan pendapatan yang diperoleh Daerah yang dipungut berdasarkan Peraturan Daerah 
sesuai dengan peraturan perundang-undangan. Pendapatan Asli Daerah bersumber dari Pajak Daerah, Retribusi Daerah, Hasil pengelolaan kekayaan Daerah yang dipisahkan dan lain-lain PAD yang sah. Semakin tinggi PAD maka semakin tinggi tingkat kemandirian dalam suatu daerah. Karenanya Pemerintah Daerah harus mengoptimalkan pengelolaan sumber pendapatan daerah yang berasal dari PAD.

Pariwisata merupakan salah satu sumber pendapatan yang potensial untuk dikembangkan sebagai salah satu sumber pendapatan daerah. Untuk memperbesar pendapatan asli daerah maka pemerintah perlu mengembangkan dan menfasilitasi tempat pariwisata agar dapat memberikan sumbangan bagi pembangunan ekonomi. Perkembangan pariwisata berdampak terhadap kondisi sosial ekonomi masyarakat, salah satu diantaranya adalah dampak pariwisata terhadap pendapatan pemerintah. Peranan pariwisata dalam penerimaan devisa dan pembentukan Produk Domestik Bruto (PDB) mengindikasikan bahwa kegiatan kepariwisataan mampu menjadi salah satu kekuatan pembangunan yang dapat diandalkan dan tetap bertahan, sehingga kebijaksanaan pembangunan dapat lebih diarahkan pada peningkatan pariwisata menjadi sektor andalan.

Sebagai sumber penerimaan pendapatan, pariwisata tidak terlepas dari pengaruh jumlah kunjungan wisatawan. Majunya sektor pariwisata disuatu daerah sangat bergantung kepada jumlah wisatawan yang berkunjung. Kedatangan wisatawan tersebut akan mendatangkan penerimaan bagi daerah yang dikunjunginya.
Bagi wisatawan mancanegara yang datang dari luar negeri,kedatangan mereka akan mendatangkan devisa dalam negara. Semakin banyaknya wisatawan yang berkunjung maka akan memberi dampak yang positif bagi Daerah Tujuan Wisata (DTW) terutama sebagai sumber pendapatan daerah (Nasrul, 2010).

Kota Banda Aceh sendiri merupakan salah satu kota wisata syariah dimana dalam sejarahnya kota Banda Aceh selain merupakan kota yang kental dengan budaya dan tradisi islam dengan pemandangan alam yang indah, juga pernah mengalami bencana gempa bumi dan tsunami pada tahun 2004 yang meninggalkan puing-puing sejarah peninggalan bencana. Berbagai peninggalan sejarah tersebut kemudian memberikan daya Tarik tersendiri bagi wisatawan nusantara maupun mancanegara. Sejalan dengan hal tersebut, sesuai dengan amanat Undang-undang No. 28 Tahun 2009 dalam pengelolaan pajak daerah, Pemerintah Kota Banda Aceh membuat Peraturan Daerah Nomor 6 Tahun 2012 Tentang Anggaran Pendapatan Dan Belanja Kota Banda Aceh Tahun Anggaran 2013, yang mengatur tentang penerimaan anggaran pendapatan asli daerah Banda Aceh dari berbagai sektor, termasuk sektor pariwisata. Penulis tertarik untuk meneliti jumlah pariwisata nusantara dan mancanegara yang berkunjung di kota Banda Aceh karena diharapkan mampu memberikan kontribusi terhadap tempat-tempat wisata dikota Banda Aceh. Sesuai latar belakang yang dikemukakan di atas maka penulis melakukan penelitian yang berjudul tentang "Pengaruh Kunjungan 
Wisatawan terhadap Pendapatan Asli Daerah dikota Banda Aceh".

Tujuan penelitian yang diharapkan adalah untuk mengetahui apakah terdapat pengaruh kunjungan wisatawan terhadap pendapatan asli daerah kota Banda Aceh. Manfaat yang bisa diambil dalam penelitian ini adalah : 1) Manfaat akademik dapat memberikan sumbangan pemikiran dan kajian teoritis mengenai wisatawan, pajak dan pendapatan asli daerah, 2) Manfaat praktis, dapat mengingatkan kewajiban dan kemauan membayar pajak, 3) Bagi peneliti lain dapat dijadikan referensi untuk penelitian selanjutnya.

\section{KAJIAN PUSTAKA}

\section{a. Pengertian Pendapatan Asli Daerah}

Pengertian pendapatan asli daerah berdasarkan Undang-Undang Nomor 33 Tahun 2004 tentang Perimbangan Keuangan Antara Pusat dan Daerah Pasal 1 angka 18 bahwa "Pendapatan asli daerah, selanjutnya disebut PAD adalah pendapatan yang diperoleh daerah yang dipungut berdasarkan peraturan daerah sesuai dengan peraturan perundang-undangan". Pendapatan Asli Daerah (PAD) merupakan pendapatan daerah yang bersumber dari hasil pajak daerah, hasil retribusi Daerah, basil pengelolaan kekayaan daerah yang dipisahkan, dan lain-lain pendapatan asli daerah yang sah, bertujuan untuk memberikan keleluasaan kepada daerah dalam menggali pendanaan dalam pelaksanaan otonomi daerah sebagai wujud asas desentralisasi.

Sejalan dengan hal itu, Pemerintah Kota
Banda Aceh membuat Peraturan Daerah Nomor 6 Tahun 2012 Tentang Anggaran Pendapatan Dan Belanja Kota Banda Aceh Tahun Anggaran 2013, yang mengatur tentang penerimaan anggaran pendapatan asli daerah Banda Aceh dari berbagai sektor, antara lain berasal dari : 1) Pajak daerah, 2) Retribusi daerah, 3) Hasil pengelolaan kekayaan daerah yang dipisahkan, 4) Lain-lain $P A D$ yang sah meliputi hasil penjualan kekayaan daerah yang tidak dipisahkan, jasa giro, pendapatan bunga, keuntungan selisih tukar rupiah terhadap mata uang asing, dan komisi, potongan, atau bentuk lain dari penjualan, pengadaan barang dan/atau jasa oleh daerah.

Halim (2004) berpendapat Pendapatan Asli Daerah (PAD) adalah penerimaan yang diperoleh daerah dari sumber-sumber dalam wilayahnya sendiri yang dipungut berdasarkan peraturan daerah sesuai dengan peraturan perundangundangan yang berlaku. Sektor pendapatan daerah memegang peranan yang sangat penting, karena melalui sektor ini dapat dilihat sejauh mana suatu daerah dapat membiayai kegiatan pemerintah dan pembangunan daerah.

Dari definisi di atas dapat disimpulkan bahwa Pendapatan Asli Daerah (PAD) adalah Pendapatan yang diperoleh dari daerah yang berasal dari Pajak daerah, retribusi daerah, bagian laba dari perusahaan daerah, penerimaan dari dinas dan pendapatan lain-lain yang merupakan sumber pendapatan murni daerah.

\section{b. Pengertian Wisatawan}

Menurut Undang-undang Nomor 10 tahun 
2009, wisatawan adalah orang yang melakukan wisata, yaitu kegiatan perjalanan yang dilakukan seseorang atau sekelompok orang dengan mengunjungi tempat tertentu dengan tujuan rekreasi, pengembangan pribadi, atau mempelajari keunikan daya tarik wisata yang dikunjungi dalam jangka waktu sementara. Pemerintah Daerah sebagai penyelenggara tempat pariwisata memiliki kewajiban memelihara dan mengelola hasil pendapatan daerahnya untuk pembangunan daerah. Wisatawan domestik merupakan wisatawan yang berasal dari daerah Indonesia sendiri, sedangkan wisatawan mancanegara merupakan wisatawan diluar kebangsaan negara Indonesia.

Menurut Heriawan (2004), pariwisata merupakan serangkaian kegiatan perjalanan yang dilakukan oleh perorangan atau keluarga atau kelompok dari tempat tinggal asalnya ke berbagai tempat lain dengan tujuan melakukan kunjungan wisata dan bukan untuk bekerja atau mencari penghasilan di tempat tujuan. Orang yang melakukan perjalanan wisata disebut wisatawan atau tourist. Batasan terhadap wisatawan juga sangat bervariasi, mulai yang umum sampai dengan yang khusus. Menurut Soekadijo (2000) wisatawan adalah orang yang mengadakan perjalanan dari tempat kediamannya tanpa menetap di tempat yang didatanginya, atau hanya untuk sementara waktu tinggal ditempat yang didatanginya. Sehingga dapat disimpulkan wisatawan adalah orang yang melakukan perjalan untuk sementara waktu, yang diselenggarakan dari suatu tempat ke tempat lain meninggalkan tempatnya semula, dengan suatu perencanaan dan dengan maksud bukan untuk berusaha dan mencari nafkah di tempat yang dikunjungi.

\section{c. Hubungan Kunjungan Wisatawan terhadap Pendapatan Asli Daerah}

Menurut Austriana (2005), semakin lama wisatawan tinggal di suatu daerah tujuan wisata, maka semakin banyak pula uang yang dibelanjakan di daerah tujuan wisata tersebut. Dengan adanya kegiatan konsumtif baik dari wisatawan domestik maupun mancanegara, maka akan memperbesar pendapatan dari sektor pariwisata suatu daerah. Kedatangan wisatawan tersebut akan mendatangkan penerimaan bagi daerah yang dikunjunginya. Nasrul (2010) juga berpendapat bahwa bagi wisatawan mancanegara yang datang dari luar negeri, kedatangan mereka akan mendatangkan devisa dalam negara. Semakin banyaknya wisatawan berkunjung maka akan memberi dampak yang positif bagi Daerah Tujuan Wisata (DTW) terutama sebagai sumber pendapatan daerah. Sehingga semakin tingginya arus kunjungan wisatawan, maka pendapatan sektor pariwisata di suatu daerah juga akan semakin meningkat.

Sedangkan menurut Budhiasa, dkk (2014) menyatakan bahwa jumlah kunjungan wisatawan domestik perpengaruh negatif terhadap pendapatan asli karena faktor yang menentukan adalah pengeluaran wisatawan itu sendiri. Novi, dkk (2014) juga menyatakan jumlah wisatawan tidak berpengaruh terhadap pendapatan asli daerah karena menurunnya jumlah wisatawan tidak mempengaruhi pendapatan.

Dari berbagai penelitian diatas, dapat 
disimpulkan bahwa jumlah kunjungan wisatawan memiliki hubungan terhadap pendapatan asli daerah apabila pendapatan yang diterima dari para wisatawan mampu meningkatkan pendapatan asli daerah.

\section{METODE PENELITIAN}

Penelitian ini menggunakan korelasi kuantitatif, yaitu menggambarkan suatu kondisi kedalam konteks kuantitatif yang direfleksikan kedalam variabel. Hal ini sesuai menurut Sugiyono (2008) yang menyebutkan bahwa penelitian korelasi ke dalam penelitian deskripsi karena penelitian tersebut merupakan usaha menggambarkan kondisi yang sudah terjadi. Variabel penelitian ini adalah jumlah wisatawan dan Pendapatan Asli Daerah.

\section{a. Populasi}

Menurut Sugiyono (2011) pengertian populasi adalah wilayah generalisasi yang terdiri atas: obyek/subyek yang mempunyai kualitas dan karakteristik tertentu yang ditetapkan oleh peneliti untuk dipelajari dan kemudian ditarik kesimpulannya. Populasi dalam penelitian ini adalah Jumlah wisatawan yang berkunjung kekota Banda Aceh dan Pendapatan Asli Daerah kota Banda Aceh.

\section{b. Sampel}

Teknik pengambilan sampel dalam penelitian ini adalah purposive sampling (sampel yang bertujuan). Pada Sampel yang digunakan dalam teknik pengambilan sampel adalah Jumlah kunjungan wisatawan domestik dan mancanegara serta Pendapatan Asli Daerah Kota Banda Aceh tahun 2012 sampai dengan 2015.

\section{Metode Analisis Data}

\section{a. Analisis Regresi Sederhana}

Penelitian ini menggunakan analisis regresi hubungan antara variabel independen $(\mathrm{X})$ dengan variabel dependen $(Y)$. Metode analisis ini menghubungkan perkembangan jumlah kunjungan wisatawan setiap tahunnya dengan pendapatan asli daerahnya. Menurut Sugiyono (2008) persamaan umum regresi linier sederhana adalah sebagai berikut :

$$
\mathrm{Y}=\mathrm{a}+\mathrm{bX}
$$

Keterangan :

$\mathrm{Y}=$ Pendapatan Asli Dareah (nilai yang diprediksikan)

$\mathrm{X}=$ Kunjungan Wisatawan

$\mathrm{a}=$ Konstanta (nilai $\mathrm{Y}$ apabila $\mathrm{X}=0$ )

$\mathrm{b}=$ Koefisien regresi

Perhitungan penelitian ini diolah menggunakan aplikasi SPSS (Statistical Product and Service Solution). Variabel-variabel dalam penelitian ini adalah jumlah kunjungan wisatawan (X) dan pendapatan asli daerah sebagai variabel dependen (Y). Adapun penjelasannya sebagai berikut :

- Variabel Independen : Jumlah Wisatawan (X), indikatornya jumlah wisatawan domestik dan mancanegara yang tercatat dalam Laporan Statistik Banda Aceh dari tahun 2012 sampai dengan 2015.

- Variabel Dependen : Pendapatan Asli Daerah (Y), Indikator pendapatan asli daerah yaitu hasil dari Pajak Hotel, Pajak Restoran, Pajak Hiburan, Pajak Reklame, Pajak Penerangan Jalan, Pajak Parkir dan Bea Perolehan Hak atas Tanah dan Bangunan (BPHTB) tahun 2012 sampai dengan 2015. 


\section{b. Uji Asumsi Klasik}

Uji Asumsi Klasik adalah pengujian asumsi-asumsi statistik yang harus dipenuhi pada analisis regresi linier. Uji Asumsi Klasik yang dilakukan penulis adalah uji heteroskedastisitas.

\section{c. Uji Normalitas}

Uji normalitas bertujuan untuk menguji apakah dalam model regresi, variabel penganggu atau residual memiliki distribusi normal. Jika terdapat normalitas, maka residual akan terdistribusi secara normal dan independen, yaitu perbedaan antara nilai prediksi dengan skor yang sesungguhnya atau error akan terdistribusi secara simetris di sekitar nilai means sama dengan nol. (Sugiyono, 2008)

\section{d. Uji T}

Uji $\mathrm{T}$ merupakan uji signifikansi yang berfungsi apabila peneliti ingin mencari makna hubungan variabel $\mathrm{X}$ terhadap $\mathrm{Y}$, maka hasil tersebut diuji dengan uji signifikansi dengan rumus yang digunakan menurut Sugiyono (2008) dalam menguji hipotesis (Uji t) penelitian ini adalah :

$$
\mathrm{t}_{\text {hitung }}=\frac{\mathrm{r} \sqrt{\mathrm{n}-2}}{\sqrt{1-\mathrm{r}^{2}}}
$$

keterangan:

\begin{tabular}{|c|c|}
\hline thitung & = Nilai uji t \\
\hline $\mathrm{r}^{2}$ & $=$ Koefisien Determinasi \\
\hline r & $=$ Koefisien korelasi \\
\hline $\mathrm{n}$ & = Jumlah Sampel \\
\hline
\end{tabular}

\section{HASIL DAN PEMBAHASAN}

a. Jumlah Wisatawan Domestik dan Mancanegara

Kota Banda Aceh memiliki banyak objek wisata yang dapat dikunjungi. Jumlah wisatawan yang terdata dari tahun 2012 sampai dengan tahun 2015 adalah:

Tabel 1. Jumlah Kunjungan Wisatawan dikota Banda Aceh pada tahun 2012 sampai dengan 2015

\begin{tabular}{|c|c|c|c|}
\hline Tahun & $\begin{array}{c}\text { Wisatawan } \\
\text { Domestik }\end{array}$ & $\begin{array}{c}\text { Wisatawan } \\
\text { Mancanegara }\end{array}$ & $\begin{array}{c}\text { Jumlah } \\
\text { Wisatawan }\end{array}$ \\
\hline 2012 & 172.646 & 4.319 & 176.965 \\
\hline 2013 & 183.286 & 4.749 & 188.035 \\
\hline 2014 & 224.939 & 11.103 & 236.042 \\
\hline 2015 & 253.790 & 13.139 & 266.929 \\
\hline Sumber : & $\begin{array}{c}\text { Badan Perencanaan Pembangunan } \\
\text { Daerah, 2016 }\end{array}$
\end{tabular}

Dari data diatas, terlihat terjadinya peningkatan pada 4 (empat) tahun terakhir data kunjungan wisatawan kekota Banda Aceh.

\section{b. Pendapatan Asli Daerah Banda Aceh}

Dengan banyaknya obyek wisata dan jumlah kunjungan wisatawan dikota Banda Aceh maka akan menunjang peningkatan pendapatan daerah Kota Banda Aceh. Hal ini dapat dilihat dari besarnya Pendapatan Asli Daerah yang dihasilkan oleh Kota Banda Aceh. Setiap tahun Pendapatan Asli Daerah di Kabupaten Banda Aceh mengalami peningkatan. Untuk mengetahui perkembangan Pendapatan Asli Daerah Kota Banda Aceh pada tahun 2012-2015 dapat dilihat dari tabel dibawah ini:

Tabel 2. Pendapatan Asli Daerah (PAD) kota Banda Aceh pada tahun 2012 sampai dengan 2015

\begin{tabular}{|c|c|}
\hline Tahun & $\begin{array}{c}\text { Pendapatan Asli } \\
\text { Daerah (PAD) }\end{array}$ \\
\hline 2012 & 99.022 \\
\hline 2013 & 129.170 \\
\hline 2014 & 171.777 \\
\hline 2015 & 209.914 \\
\hline
\end{tabular}

Sumber : Badan Perencanaan Pembangunan Daerah, 2016 
Pendapatan Asli Daerah Kota Banda Aceh setiap tahunnya terus meningkat, karena Kota Banda Aceh merupakan Kota Wisata yang berkembang. Pendapatan Asli Daerah Kota Banda Aceh didapat dari pajak daerah, retribusi daerah, pendapatan hasil pengelolaan kekayaan yang dipisahkan, dan pendapatan lain-lain yang sah.

\section{c. Pengaruh Jumlah Wisatawan terhadap}

\section{Pendapatan Asli Daerah}

Pendapatan Asli Daerah didapat dari pajak daerah, retribusi daerah, pendapatan hasil pengelolaan kekayaan yang dipisahkan, dan pendapatan lain-lain yang sah. Hasil uji regresi linier diketahui bahwa jumlah wisatawan memiliki pengaruh terhadap Pendapatan Asli Daerah Kota Banda Aceh, yaitu :

Dari tabel 3 diperoleh nilai Sig. $=0,011$ yang berarti $<$ kriteria signifikan $(0,05)$, dengan demikian model persamaan regresi berdasarkan data penelitian adalah signifikan artinya Jumlah Kunjungan Wisatawan berpengaruh terhadap Pendapatan Asli Daerah Kota Banda Aceh.

Tabel 3. Tabel Regresi Linier

\begin{tabular}{|c|c|c|c|c|c|c|}
\hline \multicolumn{7}{|c|}{ ANOVA $^{a}$} \\
\hline & & Sum of Squares & Df & Mean Square & $\mathrm{F}$ & Sig. \\
\hline \multirow{3}{*}{1} & Regression & 6910691025,674 & 1 & 6910691025,674 & 85,602 &, $011^{b}$ \\
\hline & Residual & 161461061,076 & 2 & 80730530,538 & & \\
\hline & Total & 7072152086,750 & 3 & & & \\
\hline
\end{tabular}

b. Predictors: (Constant), WISATAWAN

\section{d. Uji Asumsi Klasik}

1. Uji Heterokesdatisitas antara pengaruh jumlah wisatawan terhadap pendapatan asli daerah menunjukkan titik-titik data menyebar secara acak tidak membentuk pola tertentu, sehingga dapat disimpulkan tidak terjadi hedeterokesdatisitas.

2. Uji autokorelasi antara pengaruh jumlah wisatawan terhadap pendapatan asli daerah dapat dilihat dari nilai $\mathrm{du}<\mathrm{d}<2$-du $\mathrm{k}=2-2$ dan hasilnya $1,489<2,032<2,511$ maka nilai $d$ hitung terletak di daerah tidak ada autokorelasi positif dan negatif, dapat diartikan tidak terjadi autokorelasi.

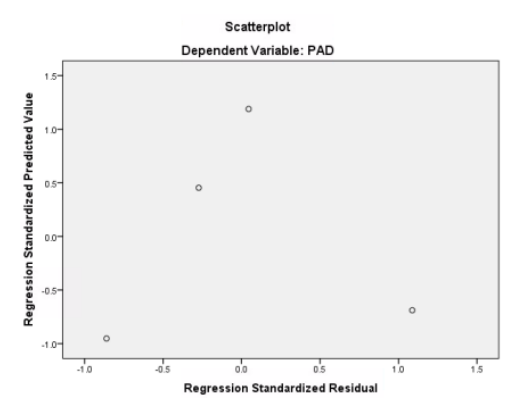

Gambar 1 : Scatterplot 
Tabel 4. Tabel Durbin-Watson

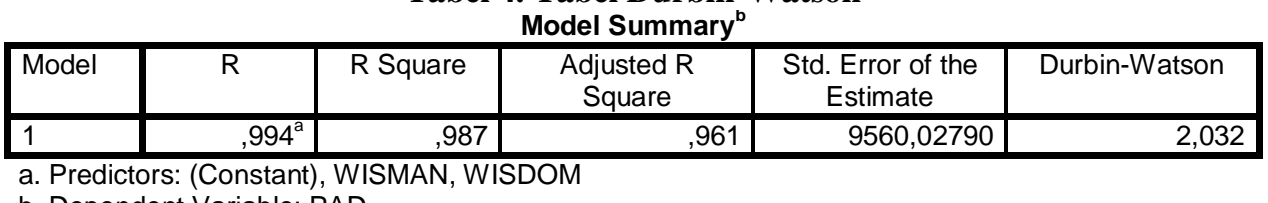

b. Dependent Variable: PAD

\section{e. Uji Normalitas}

Untuk uji normalitas data, penulis menggunakan uji Kolmogorov-Smirnov dengan taraf signifikasi 0,05 (5\%). Dibawah ini hasil uji normalitas :

Tabel 5. Tabel Kolmogorov-Smirnov

One-Sample Kolmogorov-Smirnov Test

\begin{tabular}{|ll|r|}
\hline \multicolumn{2}{|c|}{ One-Sample Kolmogorov-Smirnov Test } \\
\hline N & & $\begin{array}{c}\text { Unstandardized } \\
\text { Predicted Value }\end{array}$ \\
Normal Parameters ${ }^{\text {a,b }}$ & Mean & 4 \\
& Std. Deviation & 152470,7500000 \\
Most Extreme Differences & Absolute &, 225 \\
& Positive &, 225 \\
Kolmogorov-Smirnov Z & Negative &,- 163 \\
Asymp. Sig. (2-tailed) & &, 450 \\
a. Test distribution is Normal. &, 987 \\
b. Calculated from data. & \\
\end{tabular}

Terlihat bahwa pada tabel diatas kolom signifikan (Asymp. Sig (2-tailed)) adalah 0,987 atau probabilitas lebih dari 0,05 maka Ho diterima yang berarti populasi berdistribusi normal.

\section{f. Uji T}

Pengujian lanjutan yaitu uji signifikansi yang berfungsi apabila peneliti ingin mencari makna hubungan variabel $\mathrm{X}$ terhadap $\mathrm{Y}$, maka hasil tersebut diuji dengan uji signifikansi. Berikut ini hasil uji signifikasi :

Berdasarkan hasil uji $\mathrm{T}$ diatas diperoleh hasil korelasi antara kedua variabel, yang menghasilkan angka 9,252 dengan nilai probabilitas (sig.) 0,011. Hal ini menyatakan bahwa korelasi antara Jumlah Kunjungan Wisata dan Pendapatan Asli daerah adalah signifikan, karena nilai probabilitas $>0,05$. Dapat disimpulkan bahwa Jumlah Kunjungan Wisatawan berpengaruh terhadap Pendapatan Asli Daerah Kota Banda Aceh karena t hitung $9,252>t$ tabel 6,314

Tabel 6. Tabel t hitung Coefficients $^{\mathrm{a}}$

\begin{tabular}{|c|c|c|c|c|c|c|}
\hline \multirow{2}{*}{\multicolumn{2}{|c|}{ Model }} & \multicolumn{2}{|c|}{ Unstandardized Coefficients } & Standardized & \multirow[t]{2}{*}{$\mathrm{t}$} & \multirow[t]{2}{*}{ Sig. } \\
\hline & & B & Std. Error & Beta & & \\
\hline \multirow{2}{*}{1} & (Constant) & $-95373,987$ & 27161,951 & & $-3,511$ &, 072 \\
\hline & WISATAWAN & 1,142 &, 123 & 989 & 9,252 & ,011 \\
\hline
\end{tabular}

Berdasarkan hasil analisis dan pembahasan yang telah diuraikan, maka kesimpulan yang dapat disampaikan adalah bahwa Jumlah kunjungan wisatawan berpengaruh terhadap Pendapatan Asli Daerah Kota Banda Aceh, hal ini sejalan dengan penelitian Austriana (2005) dan Nasrul (2010) yang menyatakan bahwa Semakin banyaknya wisatawan berkunjung maka akan memberi dampak yang positif bagi Daerah Tujuan Wisata (DTW) terutama sebagai 
sumber pendapatan daerah. Sehingga semakin tingginya arus kunjungan wisatawan, maka pendapatan sektor pariwisata di suatu daerah juga akan semakin meningkat. Hal ini juga membuktikan bahwa kota Banda Aceh layak disebut sebagai kota Wisata Syariah sebagai sumber pendapatan daerahnya.

\section{KESIMPULAN DAN SARAN}

\section{Kesimpulan}

Berdasarkan hasil analisis dan pembahasan yang telah diuraikan, maka kesimpulan yang dapat disampaikan adalah bahwa Jumlah kunjungan wisatawan berpengaruh terhadap Pendapatan Asli Daerah Kota Banda Aceh, hal ini sejalan dengan penelitian Austriana (2005) dan Nasrul (2010) yang menyatakan bahwa Semakin banyaknya wisatawan berkunjung maka akan memberi dampak yang positif bagi Daerah Tujuan Wisata (DTW) terutama sebagai sumber pendapatan daerah. Sehingga semakin tingginya arus kunjungan wisatawan, maka pendapatan sektor pariwisata di suatu daerah juga akan semakin meningkat. Hal ini juga membuktikan bahwa kota Banda Aceh layak disebut sebagai kota Wisata Syariah sebagai sumber pendapatan daerahnya.

\section{Saran}

Saran diberikan untuk perbaikan penelitian selanjutnya adalah sebagai berikut :

1. Untuk mempertahankan dan meningkatkan jumlah kunjungan wisatawan maka tahun berikutnya kota Banda Aceh perlu memperbanyak aktivitas-aktivitas di obyekobyek wisata yang dapat menambah lama tinggal wisatawan yang pada nantinya memperbesar retribusi obyek wisata, sehingga akan memperbesar pendapatan asli daerah yang dapat meningkatkan anggaran pembangunan daerah. Aktivitas tersebut dapat berupa hiburan, olah raga, perkemahan, lomba-lomba dan sebagainya.

2. Pemerintah Kota Banda Aceh perlu meningkatkan kerja sama dengan masyarakat sekitar menjaga fasilitas dan kelestarian wisata dengan cara menjaga kebersihan tempat wisatanya agar wisatawan lebih tertarik lagi mengunjungi obyek wisata tersebut serta meningkatkan keamanan agar pengunjung merasa aman.

\section{DAFTAR PUSTAKA}

Austriana, Ida. (2005). Analisis Faktor yang Mempengaruhi Penerimaan Daerah dari Sektor Pariwisata. Semarang: Fakultas Ekonomi. Universitas Diponegoro.

Badan Perencanaan Pembangunan Daerah. (2016). Statistik Banda Aceh 2016. Banda Aceh: Pemerintah Kota Banda Aceh.

Budhiasa, Amerta, I Gusti Ngurah Oka \& I Gede Sudjana. (2014). Pengaruh Kunjungan Wisatawan Mancanegara, Wisatawan Domestik, Jumlah Hotel dan akomodasi Lainnya terhadap Pendapatan Asli Daerah (PAD) di Kabupaten Bandung Tahun 20012012. Bali: Universitas Udayana.

Dwi Purnawati, Novi \& Retno Mustika Dewi. (2014). Pengaruh Jumlah 
Jurnal Humaniora, 1(2), 61-70

Oktober 2017

http://jurnal.abulyatama.ac.id/humaniora

Kunjungan Wisatawan Terhadap

Pendapatan Asli Daerah Kabupaten

Mojokerto Tahun 2006-2013. Jurnal

Ekonomi, 2(3).

Halim, Abdul. (2004). Manajemen Keuangan

Daerah. Jakarta: Salemba Empat.

Heriawan, Rustam. (2004). Peranan dan

Dampak Pariwisata pada

Perekonomian Indonesia. Suatu

Pendekatan Model I-O dan SAM.

Bogor: Program Pascasarjana Institut

Pertanian Bogor.

Qadarrochman, Nasrul. (2010). Analisis

Penerimaan Daerah dari Sektor

Pariwisata di Kota Semarang dan

Faktor-Faktor

yang

Mempengaruhinya.

Semarang:

Universitas Diponogoro.

Soekadijo RG. (2000). Anatomi Priwisata,

Memahami Pariwisata sebagai

Sistematic Linkage. Jakarta: PT.

Gramedia Pustaka Utama.

Sugiyono. (2008). Metode Penelitian

Kuantitatif, Kualitatif dan $R \& D$.

Bandung: Alfabeta.

Sugiyono. (2011). Statistika Untuk

Penelitian. Bandung: Alfabeta. 